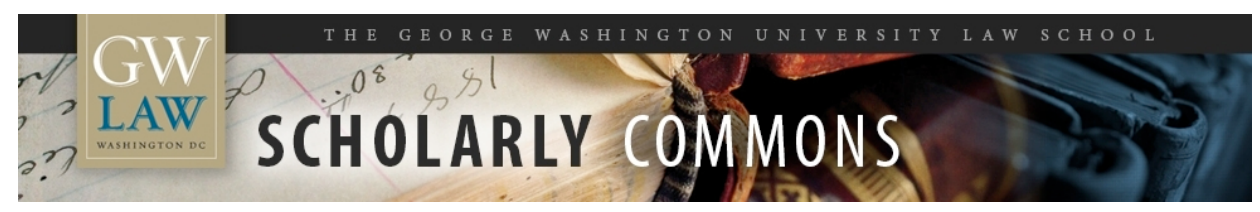

\title{
China's Legal System and the Fourth Plenum
}

Donald C. Clarke

George Washington University Law School, dclarke@law.gwu.edu

Follow this and additional works at: https://scholarship.law.gwu.edu/faculty_publications

Part of the Law Commons

\section{Recommended Citation}

Clarke, Donald C., China's Legal System and the Fourth Plenum (2015). China's Legal System and the Fourth Plenum," Asia Policy, no. 20 (July 2015), pp. 10-16, available at http://www.nbr.org/publications/ issue.aspx?id=319; GWU Law School Public Law Research Paper No. 2015-27; GWU Legal Studies Research Paper No. 2015-27. Available at SSRN: http://ssrn.com/abstract=2631042

This Article is brought to you for free and open access by the Faculty Scholarship at Scholarly Commons. It has been accepted for inclusion in GW Law Faculty Publications \& Other Works by an authorized administrator of Scholarly Commons. For more information, please contact spagel@law.gwu.edu. 
*DRAFT*

\section{China's Legal System and the Fourth Plenum}

\section{Donald Clarke}

(Pre-publication draft of Donald Clarke, China's Legal System and the Fourth Plenum, ASIA PoLICY, no. 20 (July 2015), pp. 10-16, available at http://www.nbr.org/publications/issue.aspx?id=319)

DONALD CLARKE is the David A. Weaver Research Professor of Law at the George Washington University School of Law. He can be reached at <dclarke@law.gwu.edu>

NOTE: This essay draws on Donald Clarke, “The Fourth Plenum's ‘Decision’: My Take,” Chinese Law Prof Blog, October 29, 2014, http://lawprofessors.typepad.com/china_law_prof_blog/2014/10/the-fourth-plenums-decision-mytake.html; and Donald Clarke, "Life as an Official, From the Inside,” April 25, 2015, http://lawprofessors.typepad.com/china_law_prof_blog/2015/04/life-as-an-official-from-the-inside.html. 


\section{*DRAFT*}

As the Chinese Communist Party (CCP) Central Committee’s first meeting specifically devoted to the legal system, the Fourth Plenum, held in October 2014, attracted a lot of attention from those interested in Chinese law. Anyone expecting the official Decision of the Fourth Plenum (subsequently referred to as the Decision) to show a Pauline conversion to the ideology of rule of law, however, would have been disappointed. Even if the leadership were to desire the system of accountability and institutionalized restraint on government that is generally understood by the term "rule of law," it could not be accomplished any time soon and would require changes in entrenched features of the current political and administrative system. But what about rule by law_-a system of largely predictable and rule-governed behavior by lowerlevel government administrators, even if those giving the orders are not ultimately accountable or constrained? In this essay I will argue that the Fourth Plenum Decision represents modest progress toward that goal.

The big-picture summary is that the Decision contemplates no fundamental reform in the relationship between the legal system and the CCP. It is clear that, institutionally speaking, the party will remain above the law. At the same time, the Decision does contemplate some genuinely meaningful (and in my opinion positive) reforms. It also includes many things that might look meaningful but are not.

This essay will proceed by discussing first the continuing primacy of the CCP. It will then analyze in turn some major and then some minor, yet still meaningful, reforms to the legal system. It will conclude with a discussion of an important reform that was not made: a reform in the system under which local officials administer rules but do not make them. This system inevitably results in the highly discretionary application of rules, and makes it difficult—perhaps impossible_-to develop truly rule-based government. 


\section{Party First, Law Second}

In general, whenever the party and the law appear in the same sentence in the Decision, the

party comes first. Certainly, it comes first in some important places. For example, section 1 of the decision lists several important principles that must be upheld in order to achieve the goal of ruling the state according to law. The first is leadership of the party.

Section 6 states that judges should be loyal to four things: the party, the state, the people, and the law. Notice which comes last. There is no reason, of course, why this sentence could not be interpreted as giving all elements equal value; in any list something must come first. But in a document like this, nothing — not even a comma—is accidental. The elements of this list come in the order they do for a reason. The "Three Supremes" (sange zhi shang), long associated with former Supreme People’s Court (SPC) president Wang Shengjun (on whose CV not a single day of legal education appears), are resurrected in the same section. Legal system personnel should give highest priority to the cause of the party, the interests of the people, and the constitution and laws - again, listed in that order. Lawyers must support the party’s leadership, and party cells in law firms should step up their activities.

In addition, obedience of officials to law is presented throughout as a kind of internal party policy goal: this is something that party members should do, and officials will even be scored on it (section 7, subsection 3). Those who have a special privilege mentality will be criticized and educated (piping jiaoyu), and if necessary removed from office. But because the decision contemplates no changes in the relationship between the legal system and the party, the system in which powerful officials can override law if they wish remains comfortably in place. The decision just wants them to wish to override it less often. 


\section{*DRAFT*}

\section{Major Meaningful Reforms}

Management of judicial personnel. The decision calls for significant reforms in the system of managing judges. It proposes to establish essentially a career civil-service model for the judiciary. Junior judges should be selected by provincial-level courts and should start their careers in basic-level courts. They will then be promoted to higher-level courts based on their ability. The decision does not actually specify who will do the promoting, although it would make sense for this power to be in the hands of the provincial-level courts as well. The same principle applies to procurators.

This reform is significant precisely because courts are still making their way out of the work-unit (danwei) model. The main (or at least, an important) way to become a senior judge at a high-level court is to start out as a junior judge at a high-level court-presumably by graduating with excellent grades from a famous law school. The Decision endorses the

desirability of having senior and experienced people from outside the judiciary move laterally into it, similar to how experienced lawyers cap off their career with a federal judgeship in the United States. Yet while there is much to be said for this idea, the Decision provides no detail as to how current procedures might be changed to enhance protections and no steps to my knowledge have yet been taken.

Reforms to the court system. The Decision calls for two significant reforms in the court system, both apparently designed to address the problem of local protectionism. First, the SPC is to establish "circuit tribunals” (xunhui fating) each with jurisdiction over several provinces, to try cases involving more than one province. Note that this proposal does not involve setting up another layer of courts; rather, the decisions of such tribunals are decisions of the SPC itself. Second, there is a proposal to establish another layer of courts that will cross jurisdictional 
boundaries. Such a proposal, however, would require legislative and possibly constitutional amendments. The Decision gives only a sentence to this proposal, so we know basically nothing about how it might be carried out.

In both cases, the institutions involved are intended to hear only a particular kind of case: cross-jurisdictional cases. They do not appear intended to solve the general problem caused by the dependence of courts on political power at the same administrative level. The first reform affects only the SPC, does not change its jurisdiction, and was apparently sold to the central leadership on the theory that if the SPC had seats outside of Beijing, fewer SPC petitioners would head to Beijing. The second reform is intended only to reduce the incentives of nonjudicial officials to interfere in cases, but does not affect their ability to do so should they so wish.

\section{Minor Meaningful Reforms}

The Fourth Plenum decision also proposes reforms that, while perhaps not major or groundbreaking, are nevertheless meaningful.

First, the decision calls for breaking the link between amounts received by a government agency in fines and confiscations and that agency’s (or, presumably, its officials') interests. The

old policy not only promotes excessive fines and confiscations, but it also gives enforcement agencies a stake in continued lawbreaking by those they regulate.

Second, the decision calls for control over the personnel and finances of state auditing organs to be centralized up to the provincial level. This is presumably to provide auditing bodies with more independence from local officials, who might pressure them to look the other way during their investigations. 


\section{*DRAFT*}

Third, the decision contains some welcome language on civil rights. It specifies the principle of the presumption of innocence (yi zui cong wu). ${ }^{1}$ It also endorses the principle of exclusion of unlawfully gathered evidence. I put both these items in the "meaningful but minor" category because while they are not meaningless and could be important, there have been similar measures before and problems still persist.

Fourth, the decision rather surprisingly seems to endorse an Anglo-American-type jury. At present, China has a system of “people’s assessors” (renmin peishenyuan): lay people who in certain cases sit alongside judges and have (in theory, although of course not in practice) equivalent decision-making power over the case by taking a vote at the end. The Fourth Plenum decision calls for the gradual implementation of a system whereby assessors will decide only issues of fact and not issues of law. I group this with the minor reforms because, although it would be major if actually implemented, I am not confident that it will get very far.

\section{Feel-Good Language}

The Decision calls for strengthening or increasing many things that already exist—from constraining state power to increasing legal aid. Consider, for example, that jiaqiang (strengthen) appears 61 times, jianquan (strengthen) appears 47 times, wanshan (perfect) appears 79 times, and tigao (raise or increase) appears 19 times. Promises and declarations of intention are largely meaningless, however, without specific institutional reforms. This section highlights a few examples.

Constitutional review. The decision calls for strengthening the system of constitutional review of legislation. There is such a system in place now, but it appears to be utterly

\footnotetext{
${ }^{1}$ This phrase literally translates as "when there is doubt about the crime, err on the side of finding no crime."
} 


\section{*DRAFT*}

nonfunctional. The decision does not propose a fundamentally different way of ensuring that legislation and government actions conform to the constitution. It essentially calls for maintaining the current system of potential top-down review but doing it better.

Interference with court cases. The decision denounces attempts by leading officials to interfere with court cases and calls for the establishment of a system for keeping track of such attempts. In March 2014 the Central Political-Legal Committee (a party body) issued rules to implement such a system. But the same system of incentives that now makes judges responsive to such attempts is going to make them reluctant to record and report them. Given what we know about how China operates now, it is fair to wait for strong evidence before believing this reform has taken hold and powerful officials are no longer able to interfere in cases that interest them.

\section{Dogs That Did Not Bark}

Curiously unmentioned in the Decision is an important reform mooted at last year's Third Plenum: the centralization up to the provincial level of court finances and personnel appointments. This reform, designed to counter local protectionism, is apparently already being tried out on a pilot basis in Shanghai and perhaps other places. Though popular among legal academics, the measure is controversial among judges for at least two reasons. First, judges fear that a more hierarchical system of authority will increase the power of court leaders over them. Second, judges in prosperous areas fear that putting court finances under a higher administrative authority (i.e., the province) will mean a unified salary scale for all judges under that authority. Judges in poor areas might receive higher pay, but judges in rich areas could receive less. The absence of language on this issue may well be evidence that this reform has stalled.

A welcome absence in the decision is language downplaying legal professionalism and touting closeness to the masses, a discourse that has in recent years become more prominent. The 


\section{*DRAFT*}

absence of populist language fits well into a professionalization model but not very well into the story of deprofessionalization, populism, and China turning against law. ${ }^{2}$ In addition, it suggests a greater role for court decisions as sources of legal authority and not just as one-off judgments between two disputing parties. If a court decision is merely a one-off judgment unrelated to anything else the legal system does, then it does not much matter if untrained lay people decide legal questions as well as factual ones. But if a court decision constitutes legal authority to any degree, then it is important to control who is making that decision and how he or she makes it. Professionalization of the judiciary makes it more possible for court decisions to have precedential value.

Finally, perhaps the most important dog that did not bark is the Fourth Plenum's failure to propose reforms to a long-standing feature of China's legal-administrative system that is a major obstacle to the establishment of rule-based government, whether rule by law or the more exalted rule of law: the centralization of rule-making power coupled with the decentralization of administrative power. $^{3}$ In other words, rules are made at the provincial and central levels, in which the bureaucracies tend to be woefully understaffed and do not deliver government services directly to the public. That task falls to local governments, which have limited rule-making power. Thus, rule-making is in hands of those who know little about problems of implementation.

As a result, the rules tend to be vague and leave great room for variation in local implementation.

\footnotetext{
${ }^{2}$ For work on this story of deprofessionalization, populism, and China turning against law (with which I generally agree), see Carl Minzner, “China’s Turn against Law,” American Journal of Comparative Law 59, no. 935 (2011); and Benjamin Liebman, A Return to Populist Legality? Historical Legacies and Legal Reform, in Mao's Invisible Hand, ed. Sebastian Heilmann and Elizabeth J. Perry (Cambridge: Harvard University Asia Center, 2011), 165200.

${ }^{3}$ The author owes much for the argument presented here to recent works by Wei Cui of the University of British Columbia Faculty of Law. See, in particular, Wei Cui, "Administrative Decentralization and Tax Compliance: A Transactional Cost Perspective," University of Toronto Law Journal (forthcoming); and Wei Cui, "What Is Federalism, Chinese Style? A Perspective from the Law," in The Beijing Consensus? How China Has Changed the Western Ideas of Law and Economic Development and Global Legal Practices, ed. Weitseng Chen, (New York: Cambridge University Press, forthcoming).
} 


\section{*DRAFT*}

This variation often comes down to the discretionary decisions of local officials and to that extent ceases to be law-like.

The implications of this feature of China's legal-administrative system for the rule of law are broad. Consider how the norms of securities or tax law, for example, are enforced in the United States. A great deal of reliance is placed on voluntary compliance by regulated parties, coupled with occasional audits and other after-the-fact means of detecting and punishing noncompliance. But since taxpayers and issuers cannot possibly know all the applicable laws, they rely on assistance from their lawyers. The government has cleverly managed to make the private sector pay for its own compliance efforts and, by and large, secures a high level of compliance.

But for this system to work there must be law for lawyers to become expert in. In other words, there must be a reasonably predictable and unified system of rules. Ad hoc, discretionary decisions by government officials cannot supply this kind of legal environment. Thus, regardless of what we think of ad hoc decision-making from a fairness perspective, it renders impossible a certain mode of governance that has the advantage, among others, of being much cheaper. Moreover, this system of ad hoc decision-making cannot be changed simply by central government decree. It is an artifact of administrative decentralization-a feature of China's governance with roots that are deep and long-standing.

In short, some of the fundamental obstacles to rule by law, to say nothing of rule of law, exist in the everyday practice of government regulation, long before any disputes reach the courts, and may well swamp whatever salutary effects are obtained by reforms to the system of courts and judges. 
*DRAFT*

In conclusion, the Decision of the Fourth Plenum offers some modest progress toward the CCP's rule-by-law project, including reforms in the way judges are selected and promoted. It does not, however — and is not intended to-promote external accountability for the party and its officials. 